\title{
Robotic Systems in Spine Surgery
}

\section{Spinal Cerrahide Robotik Sistemlerin Kullanulmast}

\author{
Mehmet Resid ONEN, Sait NADERI \\ Umraniye Teaching and Research Hospital, Department of Neurosurgery, Istanbul, Turkey
}

Corresponding Author: Mehmet Resid ONEN / E-mail: mresit@hotmail.com

\begin{abstract}
Surgical robotic systems have been available for almost twenty years. The first surgical robotic systems were designed as supportive systems for laparoscopic approaches in general surgery (the first procedure was a cholecystectomy in 1987). The da Vinci Robotic System is the most common system used for robotic surgery today. This system is widely used in urology, gynecology and other surgical disciplines, and recently there have been initial reports of its use in spine surgery, for transoral access and anterior approaches for lumbar inter-body fusion interventions.

SpineAssist, which is widely used in spine surgery, and Renaissance Robotic Systems, which are considered the next generation of robotic systems, are now FDA approved. These robotic systems are designed for use as guidance systems in spine instrumentation, cement augmentations and biopsies. The aim is to increase surgical accuracy while reducing the intra-operative exposure to harmful radiation to the patient and operating team personnel during the intervention. We offer a review of the published literature related to the use of robotic systems in spine surgery and provide information on using robotic systems.
\end{abstract}

KEYWORDS: Renaissance, Robotic systems, Minimally invasive spine surgery, Pedicle screws

Öz

Cerrahi robotik sistemler son yirmi yıldır kullanılmaya başlanmıştır. İlk cerrahi robotik sistemler genel cerrahi laparaskopik yaklaşımları destekleyen sistemlerdir (ilk kez 1987 yılında kolesistektomide kullanılmıştır). Günümüzde en yaygın robotik system da Vinci robotik sistemdir. Bu sistem yaygın bir şekilde üroloji, jinekoloji ve diğer cerrahi branşlarda kullanılmaktadır. Son yıllarda spinal cerrahide transoral yaklaşım ile lomber omur cisimleri arası (interbody) füzyon girişimlerinde kullanımına ilişkin yayınlar mevcuttur.

SpineAssist ve bu sistemin yeni jenerasyonu olan Rönesans robotik sistemleri spinal cerrahide en yaygın kullanılan FDA onaylı robotik sistemlerdir. Bu robotik sistemler uygulanamasada spinal enstrümantasyon, sement uygulamaları ve biyopsi girişimlerinde kılavuzluk etmek üzere tasarlanmıştır. Cerrahi doğruluğu arttırmanın yanında hasta ve ameliyathane personelinin maruz kaldığı radyasyonu azaltmayı da amaçlamaktadır. Bu çalışma, omurga cerrahisinde robotik sistemlerin kullanımına yönelik literatürleri gözden geçirerek, robotik sistemin kullanımı konusunda bilgi sunmuştur.

ANAHTAR SÖZCÜKLER: Rönesans, Robotik sistemler, Minimal invazif spinal cerrahi, Pedikül vidaları

\section{INTRODUCTION}

In the past 20 years, open surgeries have been replaced with minimal invasive surgery (MIS) approaches for many surgical procedures. Laparoscopic intervention was developed in the 1980s. Consequently, minimal invasive surgeries have become very popular for various interventions. Arthroscopy, which is a form of laparoscopy, has become an essential surgical tool for orthopedic surgeons. It is based on direct visualization via optics to compensate for the lack of field-ofview in these "key hole" surgeries. Conversely, spinal robotic guidance systems do not use optics, but instead depend on preoperative planning of a virtual surgery and later a "blinded" execution using fluoroscopy as a means of verification. These systems were developed to reduce the possibility of human errors, to perform operations by smaller incisions in a tissuesparing approach, and to enable surgeons to perform tasks that would be difficult to achieve otherwise due to a lack of field-of-view (e.g. minimally invasive procedures), lack of anatomical landmarks (e.g. revision cases) and complex trajectories (e.g spinal deformities).

Robotic systems used in today's surgical applications are still far from human-independent surgical systems as shown in science-fiction movies. Therefore, it is a better idea to name these systems "Robotic Assistant Systems".

The first robot design for surgical practice was realized by the cooperation of NASA together with the engineers of the Stanford Research Institute in the 1980s (30). The "Telepresence" surgical system was developed to enhance surgical skills. The US Department of Defense developed the SRI Telepresence System to allow military surgeons to operate on wounded soldiers by the means of a remote controlled operating system (telemanipulation). This system was designed to provide surgical interventions especially in vascular injuries and general surgical interventions. While the prototype model was not adaptable for use under combat conditions, it had a major contribution to the development of 
today's most common robotic surgery system, commercialized as da Vinci ${ }^{\circledR}$. While originally designed for cardiac surgeries, this highly adaptable system became the de facto standard of care in prostatectomies and hysterectomies and has been used in dozens of different types of surgical procedures since its launch in 2001.

Another robotic system, which is used for prostatectomies, is «Urobot», which was developed at the Singapore Nanyant Technologies Institute. However, this robotic system served as a prototype and did not go beyond its purpose of development. The PAKY robotic system developed by John Hopkins University was designed for use in percutaneous interventions of the kidney. The first commercial robot released to the market was a hip prosthesis application robot known as «RoboDoc» $(18,25)$.

Today, the most popular worldwide robotic system for spine surgeries is the Renaissance ${ }^{\mathrm{TM}}$ Surgical Guidance Robot.

\section{The da Vinci Robotic Platform}

The use of the da Vinci Robotic platform was approved by the FDA in 1999. This system consists of 5 and $8 \mathrm{~mm}$ endoscopic trocar systems inserted into the patient, four different robotic arms that operate over these systems, and high definition $3 \mathrm{D}$ images that are used by the surgeon to operate and manipulate the 4 arms (Figure 1).

When compared with classical laparoscopy, the two most significant advantages of this system are its 3D imaging and overcoming the fulcrum effect of regular laparoscopic procedures (so when you move your hand right, the robot will move right too). An easily oriented camera enables the surgeon to work in a large study area, while any tremors of the hands of the surgeon are also eliminated and great convenience is provided, especially in fine movements. The most prominent disadvantage is the lack of tactile sensation $(4,7,18)$.

If compared with laparoscopy, the da Vinci Robotic System appears to have a larger range of motion and better arm manipulation. The rigid surgical system in laparoscopy may require assistant support and therefore aggravates the working conditions of the surgeon. Advanced laparoscopic surgical interventions require a long period of experimental process (33).

Today, the da Vinci Robotic System is used in many applications, especially in many urological and gynecological procedures and surgical interventions of the gastrointestinal, thyroid and Ear-Throat-Nose disorders (Table I) $(5,6,14,27,30,33)$.

\section{ROBOTIC SYSTEM IN SPINE SURGERY}

Decompression and/or stabilization are applied in spine surgery to a various number of degenerative diseases, infections, tumors, congenital tumors and deformities. Robot technologies are used for both purposes. The da Vinci Robot System has been used for decompression processes, as in laparoscopic surgery where SpineAssist and the new generation of this technology, known as Renaissance Systems, have found solid ground for stabilization processes.

\section{da Vinci Robotic Spine Surgery}

\section{Transoral Interventions:}

Transoral initiatives were first used in 2005 by otorhinolaryngologists for a vallecular cyst excision. Surgeries related to the oral cavity and pathologies of the larynx and tongue root followed (26).

In 2006, O' Malley et al. presented a group of first robotassisted transoral surgeries. In this group, 3 squamous cell tumors were operated on. During this study, it was stated that

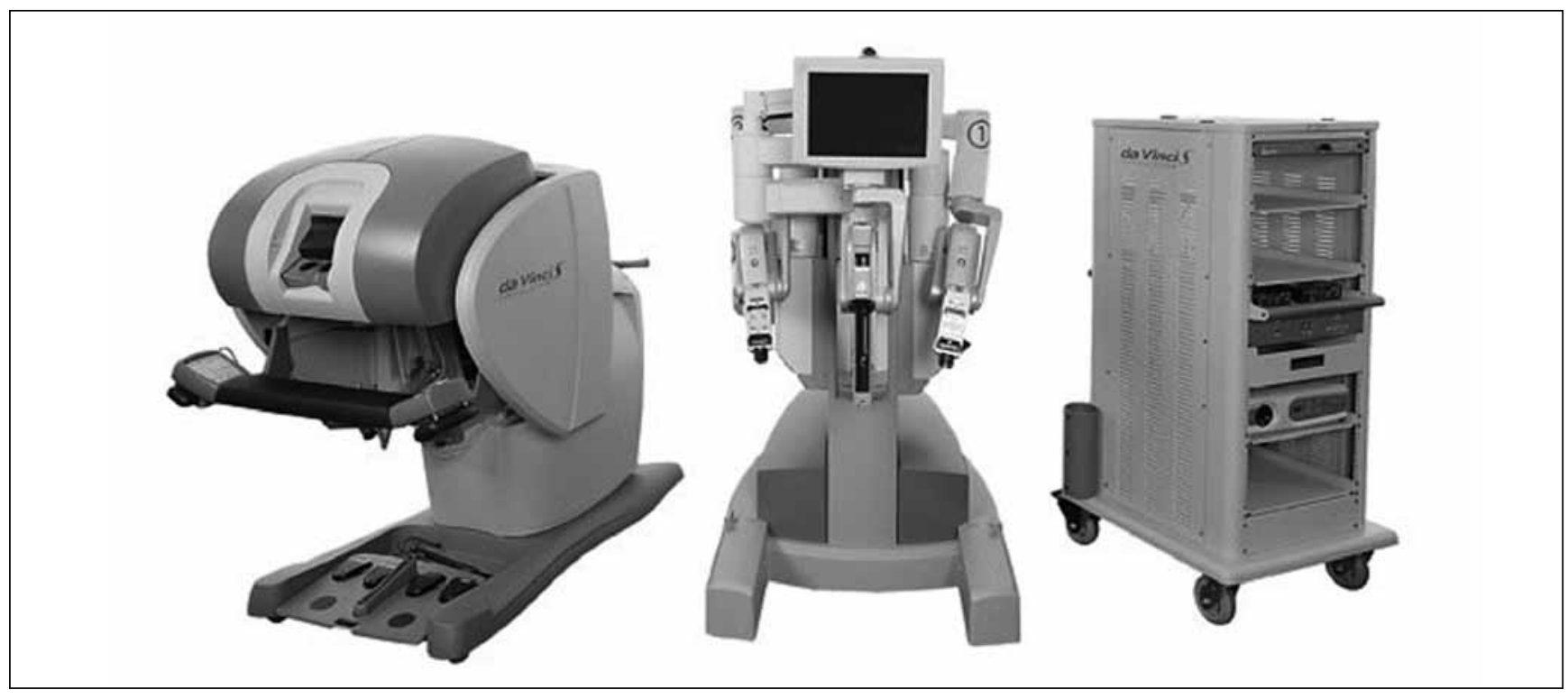

Figure 1: da Vinci robotic system (Reprinted with permission). 
Table I: Practice Areas of the da Vinci Robotic Systems

\begin{tabular}{|c|c|}
\hline General Surgery & $\begin{array}{l}\text { - Thyroid Surgery } \\
\text { - Intra-abdominal region, all approaches } \\
\text { - Gastroesophageal region } \\
\text { - Rectal region pathologies }\end{array}$ \\
\hline Urology & $\begin{array}{l}\text { - } \text { Prostate surgery } \\
\text { - } \quad \text { Retroperitoneal region pathologies }\end{array}$ \\
\hline Gynecology & - Gynecological pathologies of the lower abdominal region \\
\hline Head-Neck Surgeries & - Transoral interventions of the head base \\
\hline Neurosurgery & $\begin{array}{l}\text { - } \text { C1 - C2 pathologies by transoral means } \\
\text { - ALIF } \\
\text { - Posterior spinal surgery at experimental } \\
\text { - Surgery on tumors that can be removed only by lumbosacral anterior intervention }\end{array}$ \\
\hline
\end{tabular}

the glossopharyngeal and hypoglossal nerves were identified and the lingual artery was easily distinguished (31). Tumor excision was performed with the help of robotic surgery in a series of studies comprising 27 patients. These studies were published afterwards (40). When compared to classic approaches, it was reported that swallowing function showed a tendency to improve at an earlier stage postoperatively in patients who had robotic surgery with MIC $(29,40)$

In craniocervical pathologies where an anterior approach is necessary, transoral intervention should be applied. Clivus, C1 and C2 anterior bone and spine pathologies were operated on by the aforementioned method. However, the transoral approach is not a frequently applied type of intervention by neurosurgeons. The operating area can be very narrow and steep and the difficulty to stitch the dura and the pharynx may pave the way for the formation of a BOS fistula and infection. Unfortunately, because of the possibility that the use of the da Vinci Robotic System may not be suitable in certain routine transoral interventions, it was used for transoral approaches in cadavers and head-based animal models (22). The da Vinci Robotic System obtained FDA approval in 2012 for transoral approaches in severe myelopathy and bacillary invagination cases. For this purpose, Lee et al. applied odontoidectomy to a patient with bacillary invagination and severe myelopathy (20). In the present case, odontoid resection was successfully performed, but it was reported that a significant deficiency was experienced during the use of a robotic system regarding the utilization of a kerrison punch and bone drilling. As osseous structures are not available in the majority of robotic systems, developing instruments that overcome this gap has become an important necessity.

\section{ALIF Applications:}

In spine surgery, the lumbosacral region carries a very high risk of pseudoarthrosis. However, the risk of developing this condition is minimized with the aid of various methods with posterior interventions. However, it may be very difficult to include the anterior and middle columns that comprise the largest portion of the vertebral segment in fusion because of the lack of an appropriate level carried out by posterior approaches. Accordingly, an anterior Lumbar Interbody Fusion (ALIF) System was developed to improve this condition. Nevertheless, trying to perform this intervention by means of a transperitoneal route at the lumbar region may cause significant mortality and morbidity, such as vascular complications and retrograde ejaculation $(35,39)$. Furthermore, a large incision on the abdomen of a patient is likely not a preferred intervention when the patient is targeted for lumbar fusion by classical methods. In recent years, ALIF applications at the L4-5 and L5-S1 levels using laparoscopic approaches have been reported $(14,21)$. This intervention was successfully recognized and applied in animal and cadaver studies with the aid of the da Vinci Robotic System $(16,41)$. For the very first time, the da Vinci Robotic System was used in operations of the L5-S1 levels using a transperitoneal approach where ALIF was applied (4).

\section{SpineAssist and Renaissance Robotic Spine Surgery}

Screws used in spine surgery may extend starting from the vertebral pedicle to the corpus for spinal fusion or to provide stability of an unstable segment. Posterior pedicular screw systems are recognized as the most essential components of spine surgery and are used intensively; however, these screw systems may have complications. The percentage of screw malpositions can be $5.3-8.3 \%(8,9,11)$. Nevertheless, ratios of malposition may increase significantly in cases suffering from cervical and thoracic instrumentation in patients with scoliosis. Screw malposition in approximately 3.3-4.3\% can be seen only when cases with head scoliosis are evaluated $(1,10,17)$. Additionally, even though a malpositioned screw does not cause neural or vascular damage, the stability of a malpositioned screw has dramatically decreased and it is not desired at all. To obtain the most accurate planning and instrument placement, a C-armed scope is used in surgery rooms. However, computerized tomography is used in a limited number of centers. Accurate positioning can be difficult due to various reasons, such as two-dimensional images obtained from the $\mathrm{C}$-armed scope, degenerative 
spines, cases with scoliosis and obese patients where imaging can be deceptive or inadequate. At this point, CT may have significant advantages, but it is not commonly used. The most important disadvantage of both systems is that individuals in the operating room are exposed to a high amount of radiation $(9,23)$.

\section{SPINEASSIST ROBOTIC SYSTEM}

The safety of robotic systems is confirmed by various clinical trials and studies. Robotic systems are frequently used in spinal surgeries. The system was first presented to the market under the name SpineAssist. The system obtained approval from the FDA in 2004 for surgical applications in the brain. SpineAssist was used in more than 25 medical centers between 2005 and 2011 and in 2000 patients (3).

The operating principles of this system and its use are quite different from the da Vinci System. This robotic system acts more like a guidance system and is widely used in surgical intervention. The purpose of the system is to reach the operative site without any safety issues and errors and to avoid and minimize excessive exposure to $\mathrm{x}$-rays.

Between 2005 and 2009, Devito et al. studied many cases in a retrospective manner where SpineAssist was used. The most recent study includes $88 \%$ pedicular screwing, $10 \%$ vertebroplasty and $2 \%$ biopsy cases; the total population was 673 patients. A total number of 3,271 pedicular screws were inserted with the help of a SpineAssist robot. Results were evaluated according to the compatibility of preoperative computerized tomography images of screws inserted. Nearly $89.3 \%$ of the Group A screws matched up with the planning design, while only $2.4 \%$ of screws displayed a deviation of more than $2 \mathrm{~mm}$. A transient neurological deficit was observed in $0.7 \%$ patients. In freehand applications, screw malposition was 5.3-8.3\%, while the incidence of neurological deficits reached a percentage of $2-5 \%$. It was reported that the same study demonstrated a $50 \%$ decrease in exposure to $x$-ray radiation in patients where SpineAssist was used compared to freehand patients (9).

\section{RENAISSANCE ROBOTIC SYSTEM}

The Renaissance Robotic System is a second-generation system of the SpineAssist Robotic System that was manufactured by the Mazor Robotics Company. The system was introduced to the medical market in June 2011. Compared to the previous system, the dimensions and weight of the robotic system are smaller in the new generation system, as the system was designed with better ergonometric structure, the sensitivity of positioning was enhanced, and the new software allowed for a faster transaction process that was almost ten times faster than the previous system. Additionally, the system became more compatible with PACS and intraoperative imaging systems. Furthermore, after the 2D C-Arm output, $15 \mathrm{sec}$ manual scan provided 3D modeling while the system became usable in real-time intraoperative implant corrections (C-OnSite) and interface working was improved.

Table II: Areas Where the Renaissance Robotic System can be Used

- T3 under posterior pedicular screwing

- Biopsy of spine tumors

- T3 under + sacrum vertebro-kyphoplasty interventions

- Transfacet, translaminar screw placement

The system was designed for thoracic and lumbar vertebrae and was used in vertebral strengthening procedures with the aid of spinal instrumentation (Table II).

Steps followed in surgical procedures using the Renaissance Robotic System:

1. Preoperative planning: The spinal $\mathrm{CT}$ images related to surgical planning of the patient are loaded onto the robotic software. CT images must be compatible with the vertebral anatomy and have a $0.4-1 \mathrm{~mm}$ cross-section interval. The software converts $C T$ images into $3 \mathrm{D}$ imaging. Once the surgeon determines the vertebral segments for surgical intervention, he/she may select the localization, diameter and length of instruments and the type of the intervention. Inserted instruments can be controlled at the finest detail in 3D sagittal, coronal and axial planes. Planning data for the patient are loaded to the robot in the operating room with the help of portable memory units (Figure 2).

2. Determination of the disposable clamp kit used in surgery: An appropriate platform system and percutaneous or open surgery options are selected for the region planned for surgical intervention. There are many different alternatives, such as minimally invasive Hover $\mathrm{T}$, lumbar, and thoracic clamp kits for this purpose.

3. Registration of clamp position: To allow the robot to recognize the coordinates of a clamp inserted into the vertebra in a 3D plane, preoperative planning information is matched with preoperative $x$-ray images. This process can be performed using a disposable 3D marker kit placed onto the clamp where anterior and posterior images and oblique $\mathrm{x}$-ray images are obtained; these images are then loaded into the robot. Results are presented to the surgeon together with margin of errors. Margin of errors between 0 and $1 \mathrm{~mm}$ are acceptable by the system and consequently approved. Once the surgeon confirms the results, the transaction is continued (Figure 3).

4. Robot assembly and motion: The robot comes with a disposable kit enclosed in a sterile sheath and can be stabilized on a suitable platform with the aid of a clamp. During surgery, the stability of the platform can be increased with the aid of a second stabilizer located during the spinal process or onto the sacrum to avoid swift changes in the position of the robot due to the unexpected movements of the patient and the surgery table. The surgery point of the surgeon is determined on the computer, and a command is sent to the robot to allow for localization. After the correct coordinates are received 


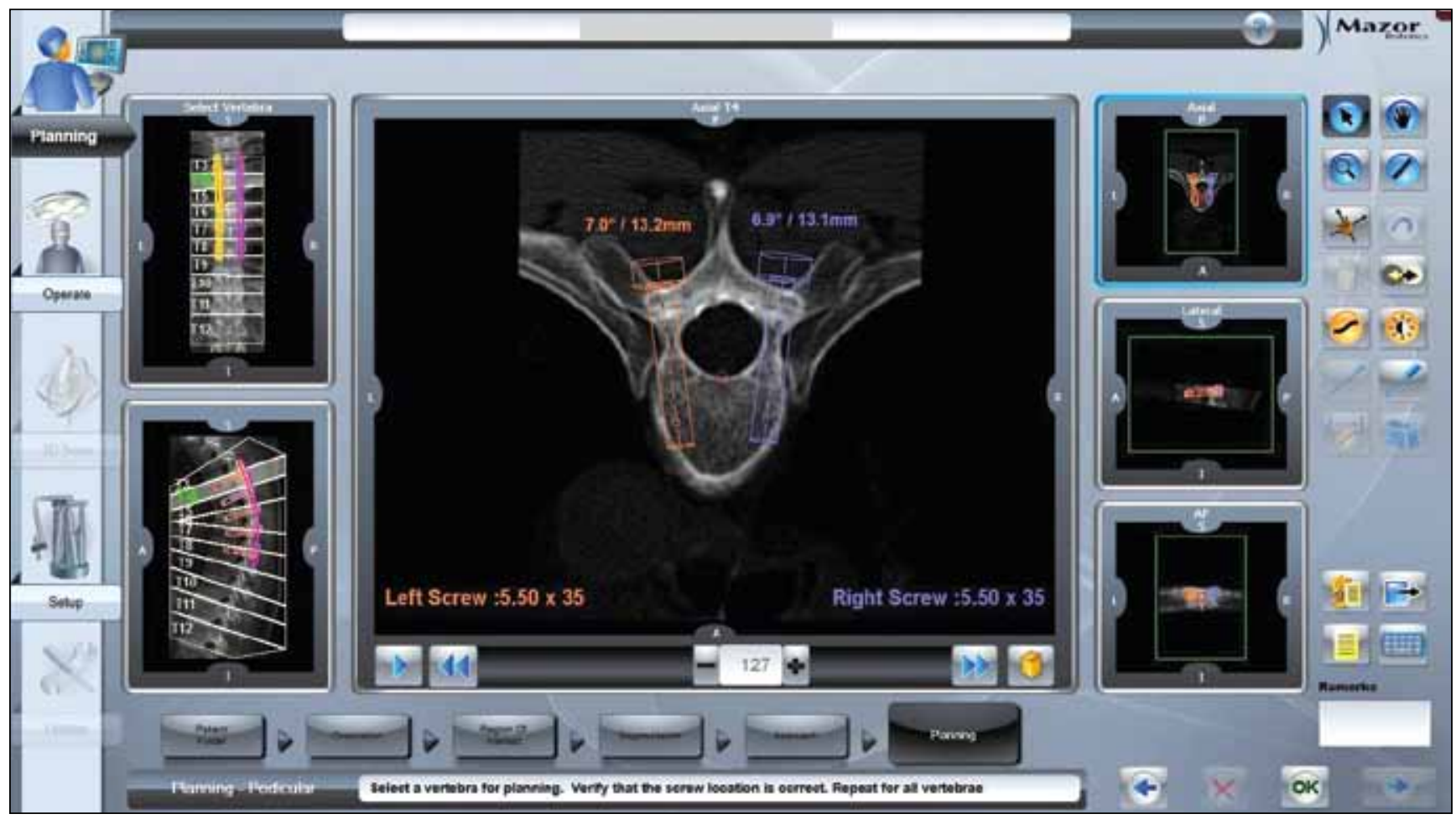

Figure 2: Preoperative planning with the software of Renassaince.

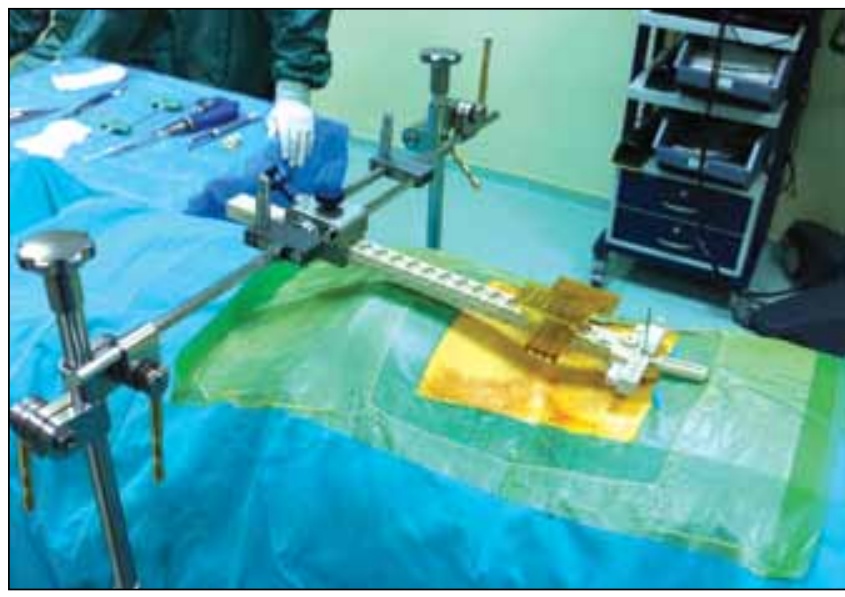

Figure 3: Clamp selection for surgery and registration of clamp position.

by the robot, gaits for a reliable trace are reported. Now the surgeon can insert the appropriate cannula and K-wires onto this trace (Figure 4).

5. Manuel application: After this stage, screws can be inserted into the determined trace by means of a K-wire, and vertebrokyphoplasty or biopsy-aimed interventions can be performed.

The use of robotic systems may increase when compared to conventional approaches due to preoperative and perioperative preparation stages. However, in patients where multi-leveled instrumentation is applied, the total surgery time may shorten due to the determination of screw locations

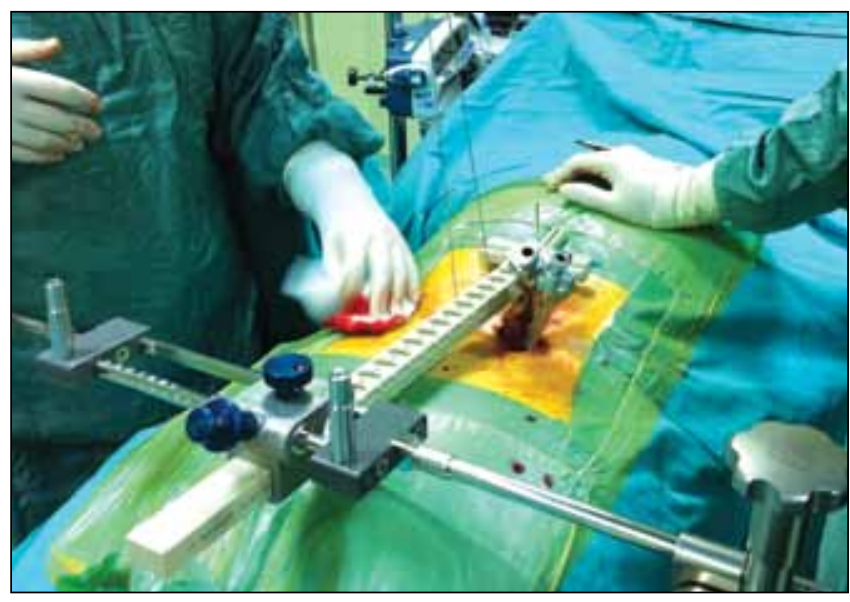

Figure 4: The correct coordinates are received by the robot and K-wires onto this trace.

and the stage where the loss in $\mathrm{x}$-ray control is reduced. The superiority of the system relies on the decreased risk of errors in cases where deformity surgery, scoliosis surgery and recurrent cases and percutaneous interventions are carried out $(12,15,43)$.

We noticed that there was a very small number of articles in the literature related to applications of Robotic Spine Surgery. In such studies, results obtained from instrumentation in different groups of disorders, and the accurate insertion of screws and deviation ratios, were reported in detail. Accordingly, in cases where robot assisted instrumentation took place, a $99 \%$ ratio regarding accurate screw location was 
Table III: Articles in the Literature Related to the Use of Renaissance Mazor Spinal Surgical Robotic Systems

\begin{tabular}{|c|c|c|c|c|c|}
\hline Author (year) & System & Application & $\begin{array}{l}\text { Percutan/ } \\
\text { Open }\end{array}$ & $\begin{array}{l}\text { Number of } \\
\text { Cases }\end{array}$ & Comment \\
\hline Sukovicz W (2006)(38) & SpineAssist & TPV & unknown & 14 cases & $93 \%$ successful \\
\hline Barzilay Y (2006) (2) & SpineAssist & TPV & $0 / 9$ & 9 cases & $\begin{array}{l}\text { Technical problems experienced } \\
\text { due to Software and patients in } \\
4 \text { cases }\end{array}$ \\
\hline Pechlivanis I (2009) (34) & SpineAssist & TPV & $31 / 31$ & 31 cases & $93.5 \%$ successful \\
\hline Kantelhard SR (2011) (15) & SpineAssist & TPV & $35 / 20$ & 55 cases & $\begin{array}{l}94.5 \% \text { successful, } 55 \% \text { decrease } \\
\text { when used in x-ray }\end{array}$ \\
\hline Zaulan Y (43) & SpineAssist & VP & 23 & 23 cases & $\begin{array}{l}65 \% \text { decrease in using } \\
\text { fluoroscopy }\end{array}$ \\
\hline $\mathrm{Hu} X(2012)(12)$ & Renaissance & TPV & $16 / 95$ & 101 cases & $98.9 \%$ successful \\
\hline
\end{tabular}

TPS: Trans Pedicular Screws, VP: Vertebroplasty.

observed; $1 \%$ of the cases had minor deviations, but these deviations were far from causing neurological or vascular damage (Table III) $(15,37)$.

\section{CONCLUSION}

As the utilization of minimally invasive surgery increases, new instrumentations are necessary. The da Vinci Robotic system has proved its reliability in many surgical interventions related to general surgery, urology, gynecology and many other surgical areas and in its contribution to MIC. It is possible to develop this system or similar systems and provide a better and more effective use in neurosurgery.

Currently, robotic spine surgery can provide better navigation, minimize malposition ratios during instrumentation, and provide a safer and more secure operation. Furthermore, it can reduce radiation during interventions and increase the safety of healthcare providers.

As seen in many new technologies, the surgeon's experience contributes significantly in reducing the ratio of errors in such systems and shortens the period of work.

\section{REFERENCES}

1. Bai YS, Niu YF, Chen ZQ, Zhu XD, Gabriel LK, Wong HK, Li $M$ : Comparison of the pedicle screws placement between electronic conductivity device and normal pedicle finder in posterior surgery of scoliosis. J Spinal Disord Tech 6:21-29, 2012

2. Barzilay $Y$, Liebergall $M$, Fridlander $A$ : Miniature robotic guidance for spine surgery-introduction of a novel system and analysis of challenges encountered during the clinical development phase at two spine centres. Int J Med Robot 2:146-153, 2006

3. Bertelsen A, Melo J, Sanchez E, Borro D: A review of surgical robots for spinal interventions. International Journal of Medical Robotics and Computer Assisted Surgery 10:45-54, 2012
4. Beutler WJ, Peppelman WC, Dimarco LA: The da Vinci robotic assisted lumbar interbody fusion: Technical development and case report. Spine 38:356-363, 2012

5. Cohn LH1, Adams DH, Couper GS, Bichell DP, Rosborough DM, Sears SP, Aranki SF: Minimally invasive cardiac valve surgery improves patient satisfaction while reducing costs of cardiac valve replacement and repair. Ann Surg 226(4):421426; discussion 427-428, 1997

6. Colonna M, Guizard AV, Schvartz C: A time trend analysis of papillary and follicular cancers as a function of tumor size: $A$ study of data from six cancer registries in France (1983-2000). European Journal of Cancer 43: 891-900, 2007

7. Copeland DR, Boneti C, Kokoska, ER, Jackson RJ, Smith S: Evaluation of initial experience and comparison of the da Vinci Surgical System with established laparoscopic and open pediatric Nissen Fundoplication surgery. JSLS 12: 238-240, 2008

8. Devito DP, Kaplan L, Dietl R, Pfeiffer M, Horne D, Silberstein B, Hardenbrook M: Clinical acceptance and accuracy assessment of spinal implants guided with spineassist surgical robot. Spine 35:2109-2115, 2010

9. Devito DP, Kaplan L, Dietl R: Clinical acceptance and accuracy assessment of spinal implants guided with Spine Assist surgical robot: Retrospective study. Spine 35:2109-2115, 2010

10. Hicks JM, Singla A, Shen FH, Arlet V: Complications of pedicle screw fixation in scoliosis surgery a systematic review. Spine 35:465-470, 2010

11. Holly LT, Foley KT: Three-dimensional fluoroscopy-guided percutaneous thoracolumbar pedicle screw placement. Technical note. J Neurosurg 99: 324 -329, 2003

12. Hu X, Ohnmeiss DD, Lieberman IH: Robotic-assisted pedicle screw placement: Lessons learned from the first 102 patients. Eur Spine J 22: 661-666, 2013

13. Huettner F, Dynda D, Ryan M, Doubet J, Crawford DL: Roboticassisted minimally invasive surgery; a useful tool in resident training--the Peoria experience, 2002-2009. Int J Med Robot 6: 386-393, 2010 
14. Inamasu J, Guiot BH: Laparoscopic anterior lumbar Interbody fusion: A review of outcome studies. Minim Invasive Neurosurg 48:340-347, 2005

15. Kantelhardt SR, Martinez R, Baerwinkel S, Burger R, Giese A, Rohde V: Perioperative course and accuracy of screw positioning in conventional, open robotic-guided and percutaneous robotic-guided, pedicle screw placement. Eur Spine J 20: 860-868, 2011

16. Kim MJ, Ha Y, Yang Ms, Yoon do H, Kim KN, Rha KH: Robot assisted anterior lumbar Interbody fusion (ALIF) using retroperitoneal approach. Acta Neurochir 152: 675-679, 2010

17. Kosmopolus V, Schizas C: Pedicle screw placement accuracy. Spine 3:111-120, 2007

18. Lanfranco AR, Castellanos AE, Desai JP, Meyers WC: Robotic surgery a current perspective. Annals of Surgery 239:14-21, 2003

19. Lee J, Yun JH, Nam KH, Choi UJ, Chung WY, Soh EY: Perioperative clinical outcomes after robotic thyroidectomy for thyroid carcinoma: A multi center study. Surgical Endoscopy 25: 906-912, 2010

20. Lee J, Lega B, Brohwick D, Newman JG, O'malley B, Weinstein GS, Grady MS, Welch WC: Da Vinci Robot Assisted trasoral odontoidectomy for basilar invagination. ORL 72:91-95, 2010

21. Lee JY, Bhowmick DA, Eun DD, Welch WC: Minimally invasive, robot-assisted, anterior lumbar interbody fusion: A technical note. J Neurol Surg A Cent Eur Neurosurg 74(4):258-261, 2013

22. Lee JY, O'Malley BW Jr, Newman JG, Wein- stein GS, Lega B, Diaz J, Grady MS: Transoral robotic surgery of craniocervical junction and atlantoaxial spine: A cadaveric study. J Neurosurg Spine 12:13-18, 2010

23. Lieberman IH, Hardenbrook MA, Wang JC: Assessment of pedicle screw placement accuracy, procedure time, and radiation exposure using a miniature robotic guidance system. J Spinal Disorder Tech 25:241-248, 2012

24. Lin S, Jiang HG, Chen ZH, Zhou SY, Liu XS, Yu JR: Meta-analysis of robotic and laparoscopic surgery for treatment of rectal cancer. World Journal of Gastroenterology 17:5214-5220, 2011

25. Lorenzo ND, Coscarella G, Faraci L, Konopacki D, Pietrantuono M, Gaspari AL: Robotic systems and surgical education. JSLS 9: 3-12, 2005

26. McCool RR, Warren FM, Wiggins RH, Hunt JP: Robotic surgery of the infratemporal fossa utilizing novel suprahyoid port. Laryngoscope 120:1738-1743, 2010

27. Morgan JA, Kohmoto T, Smith CR, Oz MC, Argenziano M: Endoscopic computer enhanced mediastinal mass resection using robotic technology. Heart Surg Forum 6:E164-166, 2003

28. Moskowitz RM, Young JL, Box GN, Paré LS, Clayman RV: Retroperitone-al transdiaphragmatic robotic-assisted laparoscopic resection of a left thoracolumbar neurofibroma. JSLS 13:6468,2009

29. Mukhija VK, Sung CK, Desai SC, Wanna G, Genden EM: Transoral robotic assisted free flap reconstruction. Otolaryngology Head and Neck Surg 140: 124-125, 2009
30. Nguyen MM, Das S: The evolution of robotic urological surgery. Urol Clin North Am 31:653-658, 2004

31. O'Malley BW Jr, Weinstein GS, Snyder W, Hockstein NG: Transoral robotic surgery (TORS) for base of tongue neoplasms. Laryngoscope 116: 1465-1472, 2006

32. O'Malley BW Jr, Weinstein GS: Robotic skull base surgery: Preclinical investigations to human clinical application. Archives of Otolaryngology-Head and Neck Surg 133: 1215-1219, 2007

33. Palep JH: Robotic assisted Minimally invasive surgery. J Minim Access Surg 5:1-7, 2009

34. Pechlivanis I, Kiriyanthan G, Engelhardt M, Scholz M, Lücke S, Harders A, Schmieder K: Percutaneous placement of pedicle screws in the lumbar spine using a bone mounted miniature robotic system first experiences and accuracy of screw placement. Spine 34:392-398, 2009

35. Quah HM, Jayne DG, Eu KW, Seow-Choen F: Bladder and sexual dysfunction following laparoscopically assisted and conventional open mesorectal resection for cancer. Br J Surg 89: 1551-1556, 2002

36. Ruurda JP, Hanlo PW, Hennipman A, Broeders IA: Robotassisted thoracoscopic resection of a benign mediastinal neurogenic tumor: Technical note. Neurosurgery 52: 462-464, 2003

37. Shoman $M$, Lieberman IH, Benzel EC, Togawa D, Zehavi $E$, Zilberstein B, Roffman M, Bruskin A, Fridlander A, Joskowicz $\mathrm{L}$, Brinkdanan S, Knoller N: Robotic assisted spinal surgery from concept to clinical practice. Computer Aided Surgery 12: 105-115, 2007

38. Sukovich W, Brink-Danan S, Hardenbrook M: Miniature robotic guidance for pedicle screw placement in posterior spinal fusion: Early clinical experience with the SpineAssist. J Med Robotics Comput Assist Surg 2: 114-122, 2006

39. Than KD, Wang AC, Rahman SU, Wilson TJ, valdivia JM, Park $\mathrm{P}$, La Marca F: Complication avoidance and management in anterior lumbar interbody fusion. Neurosurg 31(4):E6, 2011

40. Weinstein GS1, O'Malley BW Jr, Snyder W, Sherman E, Quon $\mathrm{H}$ : Transoral robotic surgery: Radical tonsillectomy. Arch Otolaryngol Head Neck Surg 133(12):1220-1226, 2007

41. Yang MS, Kim KN, Yoon DH, Pennant W, Ha Y: Robot-assisted resection of paraspinal schwannoma. J Korean Med Sci 26:150-153, 2011

42. Yang MS, Yoon DM, Kim KN, Kim H, Yang JW, Yi S, Lee JY, Jung WJ, Rha KH, Ha Y: Robot-assisted anterior lumbar interbody fusion in a Swine Model in Vivo Test of the da Vinci SurgicalAssisted Spinal Surgery System. Spine 36: 139-143, 2011

43. Zaulan Y, Alexandrovsky V, Khazin F, Silberstein B, Shoham M, Roffman M, Bruskin A: Robotic assisted vertebroplasty: Our experience with a novel approach to the treatment of vertebral compression fractures. Surgery 140: 124-125, 2009 